\title{
Planktonic carbon budget in the eastern subtropical North Atlantic
}

\author{
Emilio Marañón ${ }^{1, *}$, Valesca Pérez ${ }^{1}$, Emilio Fernández ${ }^{1}$, Ricardo Anadón ${ }^{2}$, \\ Antonio Bode ${ }^{3}$, Natalia González ${ }^{4}$, Iñaki Huskin ${ }^{5}$, Alejandro Isla ${ }^{2,6}$, \\ Xosé Anxelu G. Morán ${ }^{5}$, Beatriz Mouriño ${ }^{1}$, Mario Quevedo ${ }^{2}$, Carol Robinson ${ }^{7}$, \\ Pablo Serret ${ }^{1}$, Eva Teira' ${ }^{1}$, Marta M. Varela ${ }^{3,8}$, E. Malcolm S. Woodward ${ }^{7}$, \\ Mikhail V. Zubkov ${ }^{9}$ \\ ${ }^{1}$ Departamento de Ecología y Biología Animal, Universidad de Vigo, 36210 Vigo, Spain \\ ${ }^{2}$ Departamento de Biología de Organismos y Sistemas, Universidad de Oviedo, 33071 Oviedo, Spain \\ ${ }^{3}$ Instituto Español de Oceanografía, Centro Oceanográfico de A Coruña, 15001 A Coruña, Spain \\ ${ }^{4}$ Escuela Superior de Ciencias Experimentales y Tecnología, Universidad Rey Juan Carlos, 28933 Móstoles, Spain \\ ${ }^{5}$ Instituto Español de Oceanografía, Centro Oceanográfico de Xixón, 33212 Xixón, Spain \\ ${ }^{6}$ Leibniz Institute of Marine Sciences, Düsternbrooker Weg 20, 24105 Kiel, Germany \\ ${ }^{7}$ Plymouth Marine Laboratory, Prospect Place, West Hoe, Plymouth PL1 3DH, UK \\ ${ }^{8}$ Royal Netherlands Institute for Sea Research, PO Box 59, 1790 AB Den Burg, Texel, The Netherlands \\ ${ }^{9}$ National Oceanography Centre, University of Southampton, Southampton SO14 3ZH, UK
}

\begin{abstract}
We used data collected at > 60 stations over a $10 \mathrm{yr}$ period to build the carbon budget of the plankton community in the euphotic layer of the Eastern North Atlantic Subtropical Gyre (NASE). Autotrophic biomass exceeded microbial heterotrophic biomass by a factor of 1.7. Mean $( \pm$ SE), integrated chlorophyll a concentration and net particulate primary production (PP) were $17 \pm 1 \mathrm{mg} \mathrm{m}^{-2}$ and $271 \pm 29 \mathrm{mgC} \mathrm{m}^{-2} \mathrm{~d}^{-1}$, respectively. Protist grazing on phytoplankton represented $>90 \%$ of PP. Bacterial production (BP) was $17 \pm 3 \mathrm{mgC} \mathrm{m}^{-2} \mathrm{~d}^{-1}$. In vitro $\mathrm{O}_{2}$-evolution experiments indicated that net community production was $-65 \pm 16 \mathrm{mmolO}_{2} \mathrm{~m}^{-2} \mathrm{~d}^{-1}$, while community respiration (CR) averaged $124 \pm 13 \mathrm{mmolO}_{2} \mathrm{~m}^{-2} \mathrm{~d}^{-1}$, equivalent to $1324 \pm 142 \mathrm{mg} \mathrm{C} \mathrm{m}^{-2} \mathrm{~d}^{-1}$. However, the sum of the respiration rates by each microbial group, estimated from their biomass and metabolic rates, ranged from 402 to $848 \mathrm{mg} \mathrm{C} \mathrm{m}^{-2} \mathrm{~d}^{-1}$. Therefore, CR could not be reconciled with the respiratory fluxes sustained by each microbial group. Comparison between estimated gross photosynthesis by phytoplankton (481 to $616 \mathrm{mg} \mathrm{C} \mathrm{m}^{-2} \mathrm{~d}^{-1}$ ) and the sum of respiration by each group suggests that the microbial community in the NASE province is close to metabolic balance, which would agree with the observed $\mathrm{O}_{2}$ supersaturation in the euphotic layer. Taking into account the mean open-ocean values for PP, BP, CR and bacterial growth efficiency, we show that bacteria account for approximately $20 \%$ of CR. Our results suggest that the view that bacteria dominate carbon cycling in the unproductive ocean must be reconsidered, or else that in vitro incubations misrepresent the real metabolic rates of one or several microbial groups.
\end{abstract}

KEY WORDS: Plankton · Primary production · Bacterial production · Respiration · Grazing · Subtropical NE Atlantic · Atlantic Meridional Transect

\section{INTRODUCTION}

Despite their low areal productivity, the oligotrophic waters of the subtropical gyres are globally significant both in terms of carbon fixation and carbon export (Longhurst et al. 1995, Karl 1999). Several on-going processes of global change have the potential to affect the structure and functioning of the pelagic microbial communities in these regions. An increase in thermal stratification in the open ocean is predicted to occur as a result of sea surface warming (e.g. Sarmiento et al. 1998). This would make the upward transport of nutri- 
ents to the photic layer more difficult and reduce $\mathrm{CO}_{2}$ uptake by primary producers, thus establishing a positive feedback cycle. On the other hand, if changes in climate and land-use result in an increased supply of nutrients of continental origin to the surface of the sea, the potential exists for a negative feedback cycle whereby enhanced marine productivity might partially counteract the atmospheric $\mathrm{CO}_{2}$ build-up (Ridgwell et al. 2002). Clearly, it is only with ecological and biogeochemical models coupled to general circulation models that these complex interactions can be resolved at the global scale. However, a prerequisite for the development of such models is an adequate knowledge of the biomass, metabolism and trophic interactions of the main plankton groups. In this context, vast areas of the world ocean are still underrepresented.

For most of the year, the Eastern North Atlantic Subtropical Gyre (NASE) province is characterised by strong thermal stratification, nutrient depletion in the upper mixed layer (Longhurst 1998), low integrated chlorophyll (chl) a concentration and primary production (Marañón et al. 2000, Teira et al. 2005), a dominance of picophytoplankton $(<2 \mu \mathrm{m}$ cells $)$ in terms of both chl $a$ and primary production (Marañón et al. 2001), and a strong coupling between phytoplankton production and grazing by protists (Quevedo \& Anadón 2001). Importantly, this region is also characterised by rates of community respiration that consistently exceed those of photosynthesis (Duarte et al. 2001, González et al. 2001, Serret et al. 2001, Robinson et al. 2002). It has been hypothesised that this net heterotrophic balance is sustained by substantial inputs of organic matter from the atmosphere and the adjacent coastal upwelling off NW Africa (Duarte et al. 2001, Robinson et al. 2002). Another possibility is that the apparently negative heterotrophic balance results from an undersampling of events of intense primary production, which are likely to be missed by conventional research cruises (Karl et al. 2003). While mesoscale structures have been shown to play a relatively small role in the metabolic balance of the NASE region (Mouriño et al. 2005), experimental evidence indicates that atmospheric aerosol deposition can push community metabolism towards net autotrophy (Duarte et al. 2006).

Whatever the causes of the heterotrophic metabolic balance in the unproductive ocean, there have been few attempts to compare community respiration rates to the biomass and metabolism of each group of microbial plankton. This comparison is required to verify the consistency between the different experimental methods and also to ascertain the relative importance of each microbial group in the overall community metabolism. Robinson et al. (2002) sampled 3 stations in the NASE region and, after estimating the respiration by phytoplankton, microzooplankton and heterotrophic bacteria, found that these groups could account for 111 $\pm 34 \%$ of the total community respiration as calculated from $\mathrm{O}_{2}$ consumption during $24 \mathrm{~h}$ incubations in the dark. In contrast, in a study of 5 stations in the NASE and the adjacent North Atlantic Tropical Gyre province (NATR), Morán et al. (in press) report the existence of a significant mismatch ( $>2$-fold) between the estimated respiratory fluxes by each planktonic group and total community respiration. However, the representativeness of these studies is compromised by the fact that they are based on a small number of observations collected during single cruises at particular times of the year.

Here we use an extensive database of concurrent measurements of the biomass and metabolism of the main planktonic groups in the NASE province. Measurements were carried out over a period of $10 \mathrm{yr}$ in 13 oceanographic cruises, during which more than 60 stations were visited. Although not sufficient to resolve the seasonal trends in all variables of interest, our observations cover all seasons of the year, which, together with the relatively high number of stations visited, suggest that the dataset is representative of the region of study. The main goal of the present analysis was to construct the carbon budget of the planktonic community in the NASE province and gain further insight into its structure and metabolic functioning. We also tried to assess the consistency between the standing stocks and metabolic rates of the different microbial compartments. Specifically, we sought to determine whether community respiration, calculated from the biomass and metabolism of each microbial group, agrees with the respiration rates based on $\mathrm{O}_{2}$ consumption during in vitro incubations.

\section{MATERIALS AND METHODS}

Sampling. The results shown here were obtained during 13 cruises carried out in the NASE province from March 1992 to November 2001 (Table 1). A total of 63 stations, located within 22 to $35^{\circ} \mathrm{N}$ and 15 to $34^{\circ} \mathrm{W}$, were visited (Fig. 1). The number of stations sampled in each season was as follows: 13 in winter, 25 in spring, 9 in summer and 16 in autumn (Table 1).

Hydrography, irradiance and nutrients. The vertical distribution of temperature, salinity and fluorescence was obtained with a CTD probe attached to a rosette equipped with Niskin bottles. In most cases, photosynthetically active irradiance (PAR, 400 to $700 \mathrm{~nm}$ ) was determined by integrating measurements of downwelling irradiance at 7 Sea-WiFS wavelength bands as measured with an optical profiler. Nitrate concentration was determined with a Technicon segmented-flow 


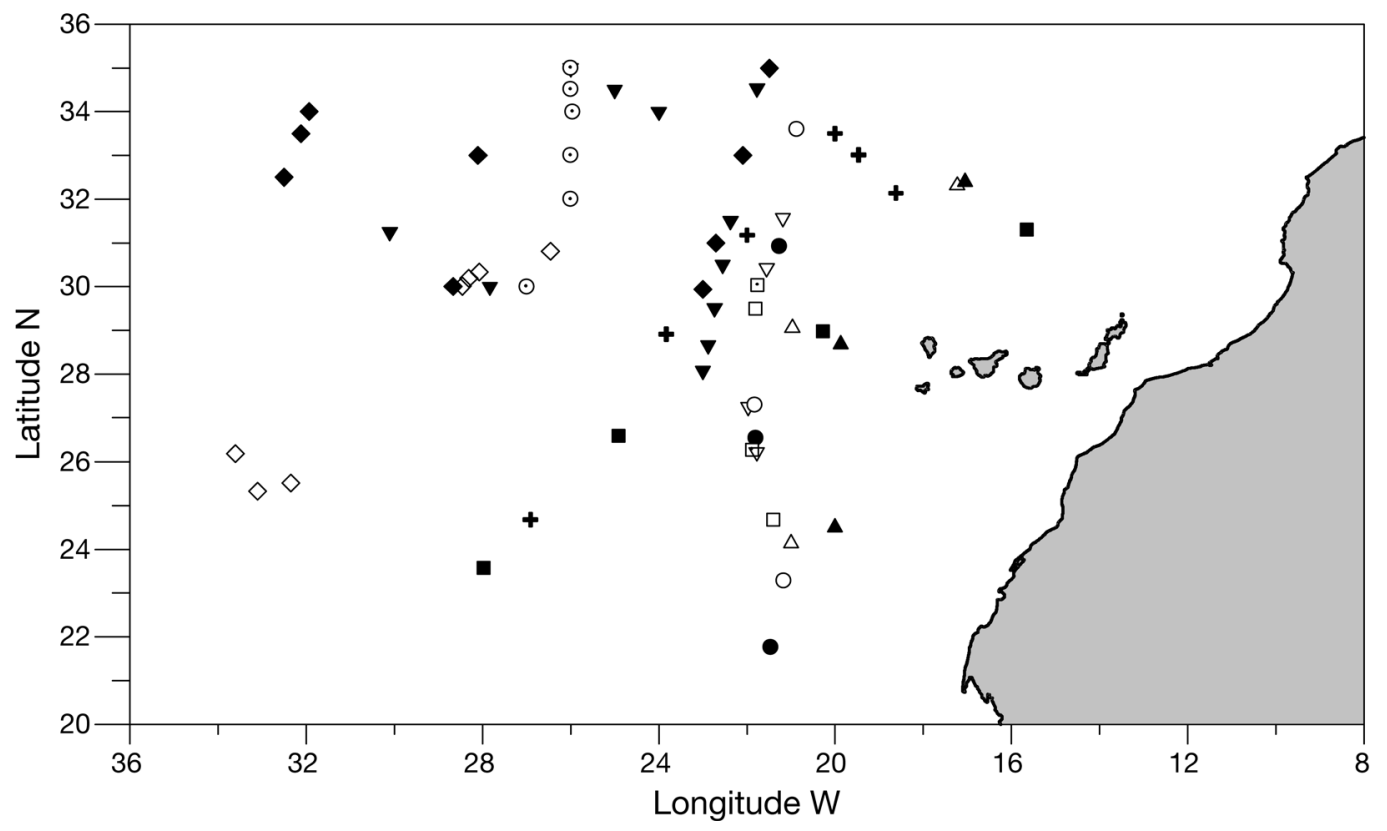

Fig. 1. Stations visited in the Eastern North Atlantic Subtropical Gyre during each cruise: AMT-1 (O), AMT-2 (๑), AMT-3 ( $\square$ ), AMT-4 $(\square)$, AMT-5 $(\Delta)$, AMT-6 $(\boldsymbol{\Delta})$, AMT-11 $(\nabla)$, Azores-1 $(\boldsymbol{\nabla})$, Azores-2 $(\diamond)$, CD-66 $(\odot)$, CD-83 $(\diamond)$, POS-237 (+), CIRCANA-1 $(\boldsymbol{\square})$

auto-analyser using standard colorimetric methods. Nitrate detection limits ranged from $25 \mathrm{nM}$ during AMT-11 to $50 \mathrm{nM}$ during the rest of the AMT cruises. The vertical distribution of dissolved $\mathrm{O}_{2}$ concentration was determined at some stations using an automated Winkler titration system. The percentage of oxygen saturation was calculated as described by Serret et al. (2001). Sampling depths for biological variables were chosen according to the vertical profiles of temperature, PAR and fluorescence. Typically, 2 to 3 depths were sampled in the upper mixed layer, and 3 to 4

Table 1. Cruises conducted in the Eastern North Atlantic Subtropical Gyre province during 1992 to 2001. Number of stations visited (n) and sampling dates are indicated for each cruise

\begin{tabular}{|c|c|c|c|c|c|}
\hline Cruise & Ship & Year & Date & Season & $\mathrm{n}$ \\
\hline CD-66 & RRS 'C. Darwin' & 1992 & 12-14 Mar & Winter & 6 \\
\hline CD-83 & RRS ‘C. Darwin’ & 1993 & 18-26 Dec & Winter & 7 \\
\hline AMT-1 & RRS 'J. C. Ross' & 1995 & $30 \mathrm{Sep}-3$ Oct & Autumn & 3 \\
\hline AMT-2 & RRS 'J. C. Ross' & 1996 & 14-16 May & Spring & 3 \\
\hline AMT-3 & RRS 'J. C. Ross' & 1996 & 28-29 Sep & Autumn & 2 \\
\hline AMT-4 & RRS ‘J. C. Ross' & 1997 & 15-17 May & Spring & 2 \\
\hline AMT-5 & RRS ‘J. C. Ross' & 1997 & 24-26 Sep & Autumn & 3 \\
\hline AMT-6 & RRS 'J. C. Ross' & 1998 & 7-9 Jun & Spring & 3 \\
\hline Azores-1 & BIO ‘Hespérides' & 1998 & 2-15 Aug & Summer & 9 \\
\hline Azores-2 & BIO ‘Hespérides' & 1999 & 8-26 Apr & Spring & 11 \\
\hline AMT-11 & RRS ‘J. C. Ross' & 2000 & 19-20 Sep & Autumn & 4 \\
\hline POS-237 & RV 'Poseidon' & 2001 & 21-26 Apr & Spring & 6 \\
\hline CIRCANA-1 & BIO ‘Hespérides' & 2001 & 30 Oct -2 Nov & Autumn & 4 \\
\hline
\end{tabular}

depths in the proximities of the deep chlorophyll maximum (DCM).

Phytoplankton biomass and primary production. Water samples were collected from 5 to 7 depths within the euphotic layer. Size-fractionated chl a concentrations were determined fluorometrically as described by Marañón et al. (2001). Water samples (100 to $250 \mathrm{ml}$ ) were sequentially filtered through 20,2 and $0.2 \mu \mathrm{m}$ polycarbonate filters and extracted in $90 \%$ acetone at $-20^{\circ} \mathrm{C}$ overnight. Total chl a concentration was determined as the sum of the size-fractionated values. During CD-66 and AMT-1 cruises, only total chl a was determined, by filtering the sample through glass fibre (Whatman GF/F) filters. Phytoplankton C biomass was estimated from size-fractionated chl a data by using the carbon to chl a ( $\mathrm{C}: \mathrm{chl}$ a) ratios obtained in the North Atlantic Subtropical gyre from flow cytometry and microscopic analysis (Pérez et al. 2006). C:chl a ratios of 103 and 21 were used for $<2 \mu \mathrm{m}$ phytoplankton in the upper mixed layer (UML) and in the DCM layer (DCML), respectively. Higher values were used for large $(>2 \mu \mathrm{m})$ phytoplankton: 247 in the UML and 60 in the DCML. The limit between the UML and the DCML was defined as the first depth where chl $a$ 
concentration exceeded $50 \%$ of the maximum value measured at that station (Pérez et al. 2006).

Size-fractionated primary production rates were measured with the ${ }^{14} \mathrm{C}$ technique by incubating water samples collected from 5 to 7 depths within the euphotic layer, as detailed by Marañón et al. (2001). Four $75 \mathrm{ml}$ acid-cleaned polystyrene bottles (3 light and 1 dark bottle) were inoculated with 370 to $740 \mathrm{KBq}$ (10 to $20 \mu \mathrm{Ci}$ ) of $\mathrm{NaH}^{14} \mathrm{CO}_{3}$ and placed in an on-deck incubator that simulated the irradiance at the original sampling depths and was refrigerated with surface seawater from the ship's continuous water supply. Incubations started at noon and lasted for 6 to $7 \mathrm{~h}$, with the exception of the AMT-11 cruise, when $24 \mathrm{~h}$ dawnto-dawn incubations were conducted. After incubation, samples were filtered sequentially through 20, 2 and $0.2 \mu \mathrm{m}$ polycarbonate filters and total primary production was determined by addition of the sizefractionated values. During cruises CD-66 and AMT-1, no size-fractionation experiments were done and therefore only total primary production was determined. Hourly ${ }^{14} \mathrm{C}$-fixation rates were converted into net particulate primary production rates by taking into account daylight duration and assuming that dark respiratory losses amount to $20 \%$ of daytime ${ }^{14} \mathrm{C}$ uptake (Geider 1992, Marra \& Barber 2004).

Bacterial biomass and production. The abundance of heterotrophic bacteria was estimated at 10 to 12 depths either by flow cytometry (AMT-3, AMT-4 and CIRCANA-1 cruises), as described by Zubkov et al. (1998) and Morán et al. (2004), or using epifluorescence microscopy on DAPI-stained samples (AMT-11 and Azores-1), as described by Bode et al. (2001). An intercalibration exercise with the 2 techniques, carried out during CIRCANA-1, indicated that epifluorescence microscopy overestimates bacterial abundance by 20\%, as some Prochlorococcus cells with low chl a content were counted as heterotrophic bacteria. We therefore accordingly corrected our estimates of bacterial abundance based on epifluorescence microscopy. In all cases, a value of $12 \mathrm{fg} \mathrm{C} \mathrm{cell}^{-1}$ was used to convert cell numbers into bacterial carbon biomass (Zubkov et al. 2000).

Bacterial production was estimated from ${ }^{14} \mathrm{C}$-leucine uptake (Zubkov et al. 2000) or ${ }^{3} \mathrm{H}$-leucine uptake (Bode et al. 2001, Morán et al. 2004) during 0.5 to $4 \mathrm{~h}$ incubations in the dark. Leucine (Leu) incorporation rates were corrected for differences between incubation and in situ temperature using the empirical correction factor calculated by Zubkov et al. (2000). Leu to carbon conversion factors (LCFs) were determined experimentally on different occasions during the cruises in which bacterial production was measured. A value of $0.67 \mathrm{kgC} \mathrm{mol} \mathrm{Leu}{ }^{-1}$ was obtained for AMT-3 and AMT-4 (Zubkov et al. 2000), while the mean LCF determined during cruises AMT-11 and CIRCANA-1

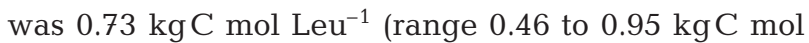
$\mathrm{Leu}^{-1}$; Morán et al. 2004). These low LCFs, which are much lower than the theoretical value of $1.55 \mathrm{kgC} \mathrm{mol}$ $\mathrm{Leu}^{-1}$ (assuming no isotope dilution), are supported by additional experiments in the subtropical North Atlantic. For instance, Zubkov et al. (2001) obtained a $\mathrm{LCF}$ of $0.4 \mathrm{kgC} \mathrm{mol} \mathrm{Leu}{ }^{-1}$ at $36^{\circ} \mathrm{N}, 20^{\circ} \mathrm{W}$. More recently, Alonso-Sáez et al. (2007) determined LCFs at 10 oligotrophic stations within the NASE region and

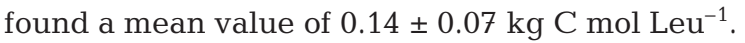

Zooplankton biomass, respiration and grazing. To determine the abundance and biomass of heterotrophic flagellates, ciliates and heterotrophic dinoflagellates, $500 \mathrm{ml}$ samples were collected from 4 to 6 depths in the euphotic layer and fixed with acidic Lugol's solution (Quevedo et al. 2003). Once in the laboratory, cell abundance and volume were determined with a phase-contrast Olympus IMT-2 inverted microscope connected to an image-analysis system. Biomass was estimated from measurements of cell volume using appropriate carbon to volume conversion equations, as described by Quevedo et al. (2003).

The average size spectrum of phagotrophic protists was built from empirical size-abundance relationships following Pareto distributions. We used 142 samples, collected along cruises AMT-5, Azores-1 and Azores-2. This size spectrum was subsequently used to estimate the average respiration of the whole assemblage of phagotrophic protists on the basis of the size scaling of metabolic rates in ciliates, dinoflagellates and heterotrophic nanoflagellates. Respiration rates were calculated by combining the slope and intercept of the average size-abundance spectrum with the allometric scaling of individual respiration rate. From unicells to large mammals, specific metabolic rates scale to body mass with an exponent consistently around -0.25 (Peters 1983). Specifically, we applied the equation proposed by Fenchel \& Finlay (1983) for the respiration rate of ciliates and flagellates. The original units were converted to carbon units following standard conversion factors (Peters 1983), resulting in the equation $R_{\mathrm{S}}$ $\left(\mathrm{h}^{-1}\right)=0.11 W(\mathrm{pg} \mathrm{C})^{-0.25}$, where $R_{\mathrm{s}}$ is mass-specific respiration rate and $W$ is body mass. We also obtained an additional, alternative estimate of respiration by phagotrophic protists based on their measured ingestion rates. For this method, we assumed that both bacterivores and herbivores excrete $20 \%$ of the ingested carbon and assimilate the remaining carbon with a growth efficiency of $25 \%$ (Robinson \& Williams 2005).

Grazing by heterotrophic protists on phytoplankton was determined by the dilution method, as explained in detail by Quevedo \& Anadón (2001). Dilution experiments were conducted with samples from the surface (5 to $7 \mathrm{~m}$ ) and the DCM depth. Samples were mixed with $0.2 \mu \mathrm{m}$ filtered seawater from the same depth to obtain 
replicate dilutions of 100,80,60, 40 and $20 \%$. An extra bottle for each dilution level was prepared and used as the initial chl a sample. After $24 \mathrm{~h}$ incubations in an ondeck incubator that simulated in situ irradiance and temperature, samples for chl a determination and flow cytometry analyses were taken. The algal net growth at each dilution level was calculated assuming exponential growth. Cell pigment content from the flow cytometry analyses was used to discard significant photoacclimation effects. Linear regression of the dilution factor against phytoplankton growth rate yields the instantaneous grazing rate and the phytoplankton growth rate (Quevedo \& Anadón 2001).

Mesozooplankton (>200 $\mu \mathrm{m}$ ) samples were collected with double WP-2 nets deployed down to $200 \mathrm{~m}$. The contents of the cod end were filtered through preweighed Whatman GF/F glass fibre filters, which were analysed in a Perkin-Elmer $2400 \mathrm{CNH}$ analyser in the laboratory to determine mesozooplankton carbon biomass (Huskin et al. 2001, Isla et al. 2004). Copepod grazing rates were determined on samples from additional net casts, using the gut fluorescence technique, as detailed by Huskin et al. (2001). To determine the initial chl a content in the gut, copepods were filtered onto Whatman sharkskin filters and stored at $-70^{\circ} \mathrm{C}$. Animals were introduced in a cool box with $0.2 \mu \mathrm{m}$ filtered seawater from the same station and kept in darkness. Three subsamples were taken every $5 \mathrm{~min}$ for $30 \mathrm{~min}$ and filtered and frozen as above. Sample fluorescence was measured after extraction in $90 \%$ acetone during $24 \mathrm{~h}$. Gut evacuation data were fitted to an exponential decay in order to determine the instantaneous gut evacuation rate. Ingestion rate was then calculated as the product of gut evacuation rate and gut chlorophyll a content. As discussed in detail by Huskin et al. (2001), the gut fluorescence technique relies on the assumption that the ingested chl a molecules do not degrade to undetectable products within the copepod gut. The rates reported here are thus likely to be minimal estimates of the grazing impact by mesozooplankton on phytoplankton.

Net community metabolism. Gross primary production (GPP), net community production (NCP) and dark community respiration (DCR) were determined at 5 to 7 depths from in vitro changes in dissolved oxygen during light and dark bottle incubations. Twelve $125 \mathrm{ml}$ borosilicate bottles were filled with seawater from each sampling depth. Four bottles were fixed immediately for initial oxygen concentrations. The remaining 8 bottles (4 light and 4 dark bottles) were incubated on deck under the same conditions as those used for ${ }^{14} \mathrm{C}$-uptake experiments. After $24 \mathrm{~h}$, dissolved oxygen concentration was determined with an automated Winkler titration system, using a potentiometric or photometric end point. Production and respiration rates were calculated as follows: $\mathrm{NCP}=\Delta \mathrm{O}_{2}$ in light bottles (mean $\left[\mathrm{O}_{2}\right]$ in $24 \mathrm{~h}$ light - mean initial $\left[\mathrm{O}_{2}\right]$ ); $\mathrm{DCR}=\Delta \mathrm{O}_{2}$ in dark bottles (mean initial $\left[\mathrm{O}_{2}\right]-$ mean $\left[\mathrm{O}_{2}\right]$ in $24 \mathrm{~h}$ dark); GPP $=\mathrm{NCP}+\mathrm{DCR}$.

\section{RESULTS}

\section{Vertical structure of the photic layer}

Although our observations were conducted over an area of more than $10^{6} \mathrm{~km}^{2}$ and during all seasons of the year, coherent patterns were observed in the vertical structure of the euphotic layer, which illustrates the relatively modest temporal and spatial variability in the hydrography of the NASE region (Fig. 2). Thermal stratification was almost always present, with the
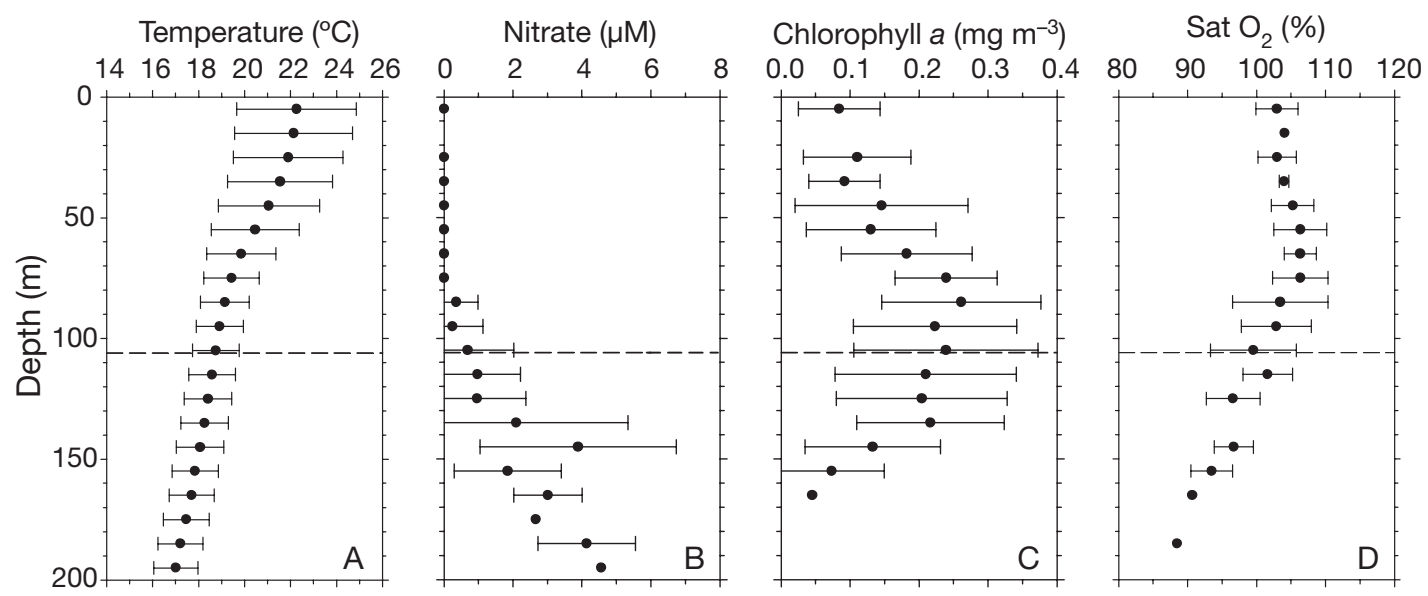

Fig. 2. Mean vertical profiles of (A) temperature, (B) nitrate concentration, (C) chl a concentration and (D) percentage $\mathrm{O}_{2}$ saturation in the upper $200 \mathrm{~m}$ of the Eastern North Atlantic Subtropical Gyre province. Bars represent \pm 1 SD. Dashed line indicates the average depth of the $1 \%$ light level 

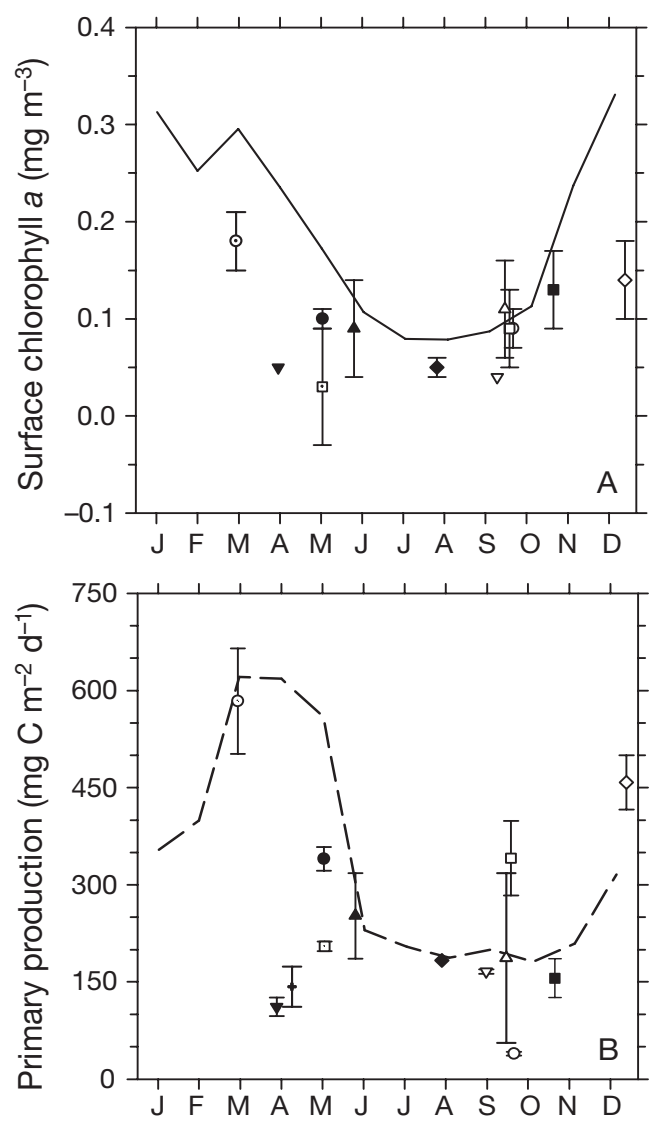

Fig. 3. Seasonal variability in (A) surface chl a concentration and (B) integrated net particulate primary production in the Eastern North Atlantic Subtropical Gyre (NASE) province. Mean values measured during each cruise are shown. Bars indicate $\pm 1 \mathrm{SE}$. Lines represent the seasonal cycle of satellitederived, surface chl a concentration (A) and integrated primary production (B) in the NASE province given by Longhurst (1998) (data taken from www.mar.dfo-mpo.gc.ca.). Symbols as in Fig. 1

steeper part of the thermocline typically being located between 50 and $80 \mathrm{~m}$ (Fig. 2A). Mean temperature in the upper mixed layer (UML, 0 to $50 \mathrm{~m}$ ) was around $22^{\circ} \mathrm{C}$ and decreased to $<19^{\circ} \mathrm{C}$ toward the base of the euphotic layer. Nitrate was close to or below the detection level in the UML but increased rapidly below the thermocline (Fig. 2B). A similar vertical pattern was observed for phosphate and silicate (data not shown). The vertical profiles of chl a concentration were characterised by low values (ca. $0.1 \mathrm{mg} \mathrm{m}^{-3}$ ) in the UML and the presence of a DCM, located between approximately 80 and $130 \mathrm{~m}$, where concentrations exceeded $0.2 \mathrm{mg} \mathrm{m}^{-3}$ (Fig. 2C). Oxygen saturation percentages $>100 \%$ were measured throughout the euphotic layer, and a local maximum with values $>105 \%$ was present at 60 to $80 \mathrm{~m}$ (Fig. 2D). The mean depth of the photic layer (1\% of surface irradiance) was $106 \mathrm{~m}$.

\section{Phytoplankton biomass and primary production}

Chl a concentration showed relatively small temporal and spatial variability during our study and was dominated by cells in the $<2 \mu \mathrm{m}$ size fraction (Fig. 3A, Table 2; see Marañón et al. 2000, Teira et al. 2005). Mean surface chl a concentrations were in the range 0.04 to $0.18 \mathrm{mg} \mathrm{m}^{-3}$ and showed a slight peak during the spring and winter cruises (Fig. 3A). Cruise-averaged, integrated chl a concentrations ranged between 11 and $25 \mathrm{mg} \mathrm{m}^{-2}$ (Table 2). The overall, mean ( $\pm \mathrm{SE}$ ) integrated chl a concentration in the NASE province during our study was $17 \pm 1 \mathrm{mg} \mathrm{m}^{-2}$. The mean contribution of picophytoplankton to total integrated chl a concentration was $71 \pm 1 \%$. Applying the average $\mathrm{C}$ to chl a ratios determined for the UML and the DCM in the NASE province (Pérez et al. 2006), we estimated the integrated phytoplankton carbon biomass at each station. Cruise-averaged phytoplankton biomass ranged between 793 and $1923 \mathrm{mg} \mathrm{C} \mathrm{m}^{-2}$, and the overall mean value was $1391 \pm 86 \mathrm{mg} \mathrm{C} \mathrm{m}^{-2}$.

Although inter-cruise differences in primary production were larger than those found in chl a concentration, mean rates of net particulate primary production ranged, in most cruises, from 100 to $400 \mathrm{mg} \mathrm{C} \mathrm{m}^{-2} \mathrm{~d}^{-1}$ (Fig. 3B, Table 2; see Teira et al. 2005). The highest mean production rates were measured during spring and winter. The average productivity of NASE during

Table 2. Mean $( \pm \mathrm{SE}) \mathrm{chl}$ a concentration $\left(\mathrm{mg} \mathrm{m}^{-2}\right)$, net particulate primary production ( $\mathrm{PP}, \mathrm{mg} \mathrm{C} \mathrm{m}^{-2} \mathrm{~d}^{-1}$ ) and relative contribution (\%) of picophytoplankton (cells $<2 \mu \mathrm{m}$ ) to total chl a concentration and primary production during each cruise. All variables were vertically integrated over the depth of the euphotic layer. Also given are overall mean values for the sum of all stations sampled during the study. n: number of stations sampled during each cruise

\begin{tabular}{|lrrcccl|}
\hline Date & $\mathrm{n}$ & Chl $a \begin{array}{c}\% \text { chl } a \\
<2 \mu \mathrm{m}\end{array}$ & $\mathrm{PP}$ & $\begin{array}{c}\% \mathrm{PP} \\
<2 \mu \mathrm{m}\end{array}$ \\
\hline Mar 1992 & 6 & $13 \pm 2$ & & 6 & $584 \pm 81$ & \\
Dec 1993 & 7 & $16 \pm 2$ & & 7 & $458 \pm 42$ & \\
Oct 1995 & 3 & $25 \pm 3$ & & 3 & $39 \pm 3$ & \\
May 1996 & 3 & $24 \pm 2$ & $72 \pm 1$ & 3 & $340 \pm 18$ & $60 \pm 3$ \\
Sep 1996 & 2 & $19 \pm 4$ & $75 \pm 1$ & 2 & $341 \pm 57$ & $41 \pm 0.2$ \\
May 1997 & 2 & $18 \pm 5$ & $83 \pm 1$ & 2 & $205 \pm 8$ & $43 \pm 3$ \\
Sep 1997 & 2 & $22 \pm 1$ & $82 \pm 3$ & 2 & $187 \pm 131$ & $67 \pm 13$ \\
Jun 1998 & 3 & $21 \pm 2$ & $71 \pm 2$ & 3 & $252 \pm 66$ & $47 \pm 1$ \\
Aug 1998 & 4 & $20 \pm 1$ & $67 \pm 4$ & 1 & 183 & \\
Apr 1999 & 10 & $13 \pm 1$ & $67 \pm 3$ & 6 & $112 \pm 14$ & $61 \pm 3$ \\
Sep 2000 & 4 & $11 \pm 2$ & $70 \pm 3$ & 2 & $166 \pm 4$ & $51 \pm 5$ \\
Apr 2001 & & & & 6 & $143 \pm 31$ & $59 \pm 5$ \\
Nov 2001 & 4 & $25 \pm 3$ & $75 \pm 2$ & 4 & $156 \pm 30$ & $43 \pm 5$ \\
Total & 50 & & & 47 & & \\
Overall mean & $17 \pm 1$ & $71 \pm 1$ & & $271 \pm 29$ & $54 \pm 2$ \\
\hline
\end{tabular}


Table 3. Mean $( \pm \mathrm{SE})$ bacterial biomass $\left(\mathrm{BB}, \mathrm{mgC} \mathrm{m}^{-2}\right)$ and production (BP, $\mathrm{mgC} \mathrm{m}^{-2} \mathrm{~d}^{-1}$ ) integrated over the euphotic layer. Also shown is the ratio between $\mathrm{BP}$ and net particulate primary production (PP). n: number of stations sampled

\begin{tabular}{|lrlrcrc|}
\hline Date & $\mathrm{n}$ & \multicolumn{1}{c}{$\mathrm{BB}$} & $\mathrm{n}$ & $\mathrm{BP}$ & $\mathrm{n}$ & $\mathrm{BP} / \mathrm{PP}$ \\
\hline Sep 1996 & 2 & $192 \pm 2$ & 2 & $19 \pm 3$ & 2 & $0.05 \pm 0.02$ \\
May 1997 & 2 & $407 \pm 84$ & 2 & $31 \pm 2$ & 2 & $0.12 \pm 0.002$ \\
Aug 1998 & 5 & $169 \pm 8$ & & & & \\
Sep 2000 & 3 & $391 \pm 5$ & 3 & $12 \pm 3$ & 2 & $0.05 \pm 0.01$ \\
Nov 2001 & 4 & $891 \pm 117$ & 4 & $14 \pm 1$ & 4 & $0.07 \pm 0.01$ \\
Total & 16 & & 11 & & 10 & \\
Overall mean & $424 \pm 79$ & & $17 \pm 3$ & & $0.07 \pm 0.01$ \\
\hline
\end{tabular}

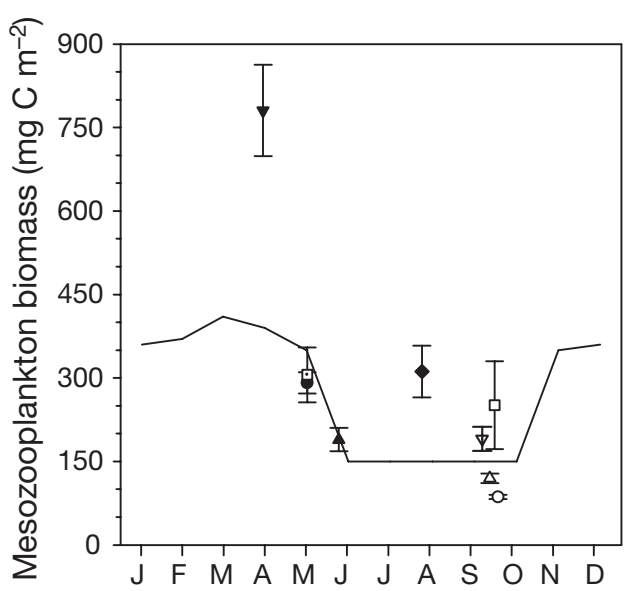

Fig. 4. Seasonal variability in integrated mesozoplankton $(>200 \mu \mathrm{m})$ biomass in the Eastern North Atlantic Subtropical Gyre province. Mean values measured during each cruise are shown. Bars indicate $\pm 1 \mathrm{SE}$. Line represents the seasonal cycle of mesozooplankton biomass derived by Finenko et al.

(2003) for the tropical North Atlantic. Symbols as in Fig. 1

our study was $271 \pm 29 \mathrm{mgC} \mathrm{m}^{-2} \mathrm{~d}^{-1}$ (Table 2), and the relative contribution of picophytoplankton to total carbon fixation was $54 \pm 2 \%$.

\section{Bacterial biomass and production}

Mean bacterial biomass and production during each cruise were in the range 192 to $891 \mathrm{mg} \mathrm{C} \mathrm{m}^{-2}$ and 12 to $31 \mathrm{mgC} \mathrm{m}^{-2} \mathrm{~d}^{-1}$, respectively (Table 3; see Zubkov et al. 1998, 2000, Morán et al. 2004). Although the number of cruises was not sufficient to ascertain the seasonal variability in bacterial biomass and production, our results consistently indicate that bacterial production was low compared to primary production; the overall average for the ratio between these 2 variables was $0.07 \pm 0.01$

\section{Zooplankton biomass and grazing}

The average biomass of phagotrophic protists was $408 \mathrm{mgC} \mathrm{m}^{-2}$, of which $71 \%$ was accounted for by heterotrophic nanoflagellates. Grazing by protists upon phytoplankton was determined during 2 cruises, in August 1998 and April 1999 (Quevedo \& Anadón 2001). In both cruises, relatively high grazing rates were measured: the overall mean ingestion rate by herbivorous protists, expressed as a percentage of net particulate primary production, was $99 \pm 36 \%$.

Mesozooplankton biomass typically ranged between 100 and $300 \mathrm{mg} \mathrm{C} \mathrm{m}^{-2}$ during the spring and summer months (Fig. 4; see Huskin et al. 2001). An exception was April 1999, when markedly higher values of inte-

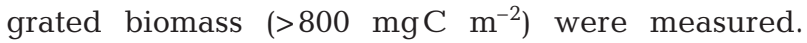
Mesozooplankton grazing rates showed a relatively small degree of variability between cruises (Table 4). The overall mean grazing rate was $28 \pm 4 \mathrm{mgC} \mathrm{m}^{-2}$, which translated into a mean value of $19 \pm 4 \%$ for the fraction of net particulate primary production ingested by mesozooplankton (Table 4).

\section{Community production and respiration}

The metabolic balance of the microbial community, as determined with the $\mathrm{O}_{2}$ evolution method, was consistently net heterotrophic during all cruises (Table 5). Cruise-averaged NCP ranged between -137 and $-19 \mathrm{mmolO}_{2} \mathrm{~m}^{-2} \mathrm{~d}^{-1}$, whereas community respiration (CR) varied within the range 54 to $181 \mathrm{mmolO}_{2} \mathrm{~m}^{-2} \mathrm{~d}^{-1}$. For the ensemble of all 14 stations where $\mathrm{O}_{2}$ evolution experiments were conducted, NCP and CR had mean values of $-65 \pm 16$ and $124 \pm 13 \mathrm{mmolO}_{2} \mathrm{~m}^{-2} \mathrm{~d}^{-1}$, respectively, while gross production averaged $57 \pm$ $9 \mathrm{mmolO}_{2} \mathrm{~m}^{-2} \mathrm{~d}^{-1}$.

Table 4. Mean $( \pm \mathrm{SE})$, depth-integrated mesozooplankton (200 to $2000 \mu \mathrm{m})$ grazing rates $\left(\mathrm{mg} \mathrm{C} \mathrm{m}^{-2} \mathrm{~d}^{-1}\right)$ and percentage of net particulate primary production (PP) ingested daily by mesozooplankton. n: number of stations sampled

\begin{tabular}{|lrccc|}
\hline Date & $\mathrm{n}$ & $\begin{array}{c}\text { Grazing } \\
\text { rate }\end{array}$ & $\mathrm{n}$ & $\begin{array}{c}\% \text { daily PP } \\
\text { ingested }\end{array}$ \\
\hline May 1997 & 2 & $14 \pm 6$ & 2 & $7 \pm 3$ \\
Sep 1997 & 3 & $15 \pm 2$ & 2 & $14 \pm 10$ \\
Jun 1998 & 2 & $14 \pm 4$ & 2 & $6 \pm 1$ \\
Aug 1998 & 9 & $32 \pm 8$ & 1 & 20 \\
Apr 1999 & 11 & $36 \pm 5$ & 5 & $27 \pm 3$ \\
Sep 2000 & 1 & 9 & 1 & 6 \\
Total & 28 & & 13 & $19 \pm 4$ \\
Overall mean & & $28 \pm 4$ & & \\
\hline
\end{tabular}


Table 5. Mean $( \pm \mathrm{SE})$ depth-integrated rates $\left(\mathrm{mmolO}_{2} \mathrm{~m}^{-2} \mathrm{~d}^{-1}\right)$ of net community production (NCP), community respiration (CR) and gross production (GP). n: number of stations sampled. GP does not always equal the sum of NCP and CR because in some stations concurrent NCP and CR data were not available for all sampling depths

\begin{tabular}{|lrccl|}
\hline Date & $\mathrm{n}$ & $\mathrm{NCP}$ & $\mathrm{CR}$ & $\mathrm{GP}$ \\
\hline Sep 1997 & 2 & $-81 \pm 21$ & $121 \pm 7$ & $40 \pm 14$ \\
Jun 1998 & 2 & $-127 \pm 12$ & $169 \pm 30$ & $48 \pm 37$ \\
Aug 1998 & 2 & $-137 \pm 37$ & $181 \pm 28$ & $44 \pm 9$ \\
Apr 1999 & 3 & $-26 \pm 33$ & $124 \pm 20$ & $98 \pm 22$ \\
Sep 2000 & 2 & $-19 \pm 2$ & $54 \pm 17$ & $35 \pm 15$ \\
Nov 2001 & 3 & $-35 \pm 27$ & $104 \pm 26$ & $57 \pm 19$ \\
Total & 14 & & & \\
Overall mean & & $-65 \pm 16$ & $124 \pm 13$ & $57 \pm 9$ \\
\hline
\end{tabular}

\section{Planktonic carbon budget}

Our measurements of microbial biomass and metabolism were conducted over a $10 \mathrm{yr}$ period in different seasons of the year and covered a large geographical region. In particular, some stations were located to the south of the Azores subtropical front, while others were located to the north. Given the importance of this mesoscale feature as a biogeographic limit within the subtropical North Atlantic, the fact that we considered stations at both sides of the front may have resulted in an increased degree of variability in our measurements. However, despite the wide temporal and geographical coverage of our data set, our results were quite consistent and, in general, showed a relatively low degree of variability both within and between cruises (Tables 2 to 5). We therefore considered it appropriate to combine all available biomass and rate measurements in order to construct the carbon budget for the plankton community in the NASE province (Fig. 5).

Phytoplankton represented the major pool of living carbon, with a mean biomass of around $1400 \mathrm{mg} \mathrm{C} \mathrm{m}^{-2}$, of which $46 \%$ was accounted for by picophytoplankton. Heterotrophic biomass was distributed evenly between bacteria $\left(424 \pm 79 \mathrm{mg} \mathrm{C} \mathrm{m}^{-2}\right)$, heterotrophic protists $\left(408 \pm 15 \mathrm{mgC} \mathrm{m}^{-2}\right)$ and mesozooplankton $\left(452 \pm 59 \mathrm{mgC} \mathrm{m}^{-2}\right)$. For the entire study, the autotrophic to heterotrophic biomass ratio in plankton was 1.07. If only the microbial components of plankton are considered, the autotrophic to heterotrophic biomass ratio was 1.7 .

To estimate phytoplankton gross production, we took into account that $18 \%$ of the total ${ }^{14} \mathrm{C}$ fixed by phytoplankton is released as dissolved organic carbon,

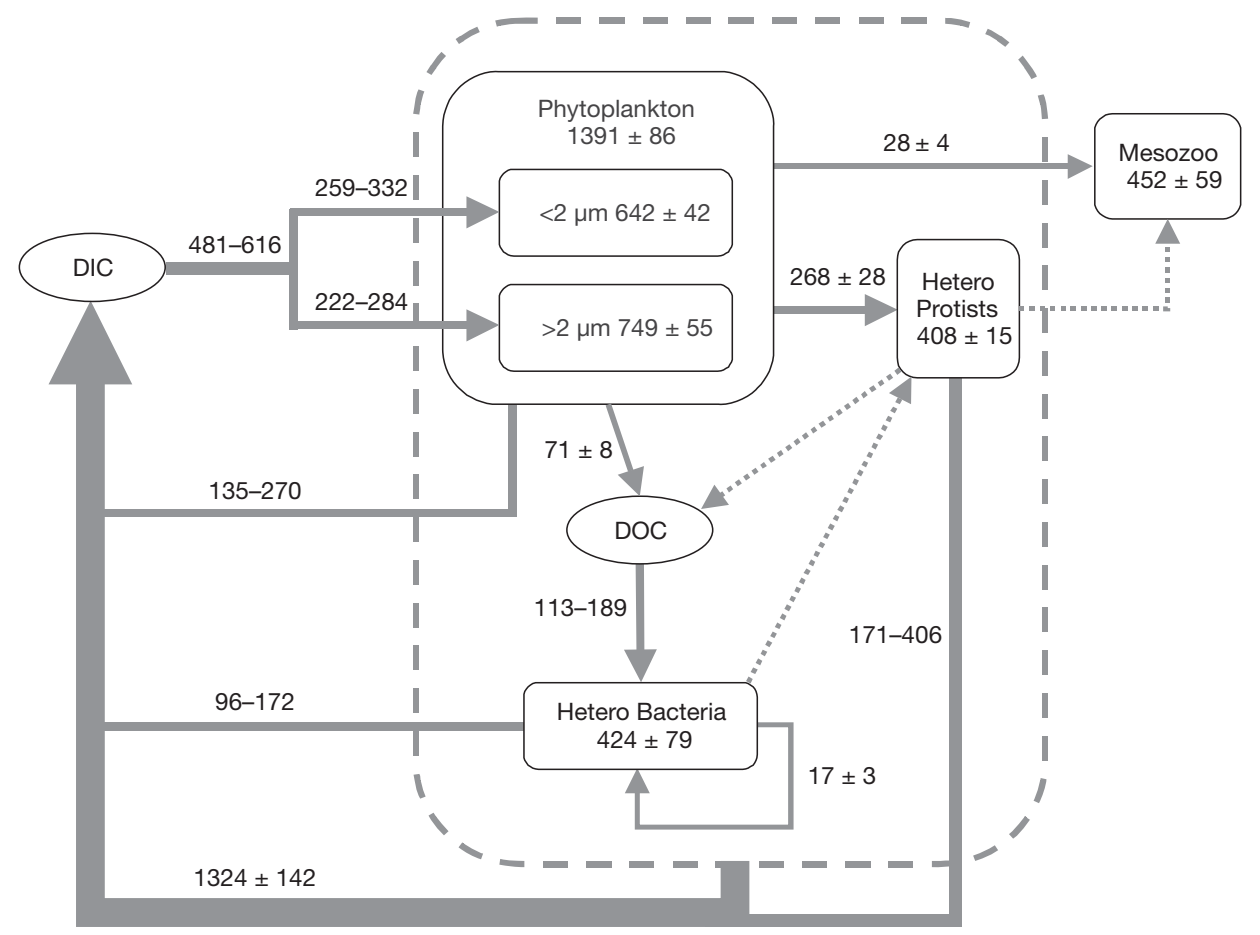

Fig. 5. Planktonic carbon budget for the euphotic layer of the Eastern North Atlantic Subtropical Gyre province. Mean values $( \pm \mathrm{SE})$ of standing stocks and fluxes are expressed in $\mathrm{mg} \mathrm{C} \mathrm{m}^{-2}$ and $\mathrm{mg} \mathrm{C} \mathrm{m}^{-2} \mathrm{~d}^{-1}$, respectively. For fluxes that were estimated rather than measured directly, ranges instead of mean values are given. Dissolved inorganic carbon (DIC) fluxes into phytoplankton represent gross photosynthesis. Dotted lines indicate fluxes that were not determined in this study. See 'Materials and methods' for details on calculations 
as experimentally determined by Teira et al. (2003) in the NASE province. We then assumed that phytoplankton dark respiration amounts to between 20 and $40 \%$ of the daylight carbon uptake and that phytoplankton respire at the same rate during the day and during the night (Geider 1992, Langdon 1993, Marra \& Barber 2004). The corresponding phytoplankton respiration would thus range between 135 and $270 \mathrm{mgC}$ $\mathrm{m}^{-2} \mathrm{~d}^{-1}$. The resulting range of estimated gross phytoplankton production was 481 to $616 \mathrm{mg} \mathrm{C} \mathrm{m}^{-2} \mathrm{~d}^{-1}$, of which $54 \%$ would be carried out by picophytoplankton. A substantial loss process for phytoplankton was grazing by protists $\left(268 \pm 28 \mathrm{mgC} \mathrm{m}^{-2} \mathrm{~d}^{-1}\right)$, while mesozooplankton grazing on phytoplankton was an order of magnitude smaller (Fig. 5).

Measurements of bacterial production (BP) can be used to estimate bacterial respiration (BR) and bacterial carbon demand $(\mathrm{BCD}=\mathrm{BP}+\mathrm{BR})$, provided that bacterial growth efficiency $(\mathrm{BGE}=\mathrm{BP} / \mathrm{BCD})$ is known. Recently, Alonso-Sáez et al. (2007) experimentally determined BGE along 2 longitudinal transects (21 and $26^{\circ} \mathrm{N}$ ) in the NASE province. They reported a mean $( \pm \mathrm{SE}) \mathrm{BGE}$ of $0.09 \pm 0.015$ from measurements conducted at 10 different stations. After reviewing the literature, del Giorgio \& Cole (2000) concluded that the average BGE in the open ocean is 0.15. A more recent review, presented by Alonso-Sáez et al. (2007; see their Web Appendix 3) gives a mean open-ocean value of 0.12 . We therefore calculated lower and upper estimates for BR by applying BGE values of 0.09 and 0.15 to our mean values of $\mathrm{BP}$. The resulting range of estimated BR in the NASE province is 96 to $172 \mathrm{mg} \mathrm{C} \mathrm{m}^{-2}$ $\mathrm{d}^{-1}$. The corresponding range for BCD would then be 113 to $189 \mathrm{mg} \mathrm{C} \mathrm{m}^{-2} \mathrm{~d}^{-1}$ (Fig. 5).

Respiration by phagotrophic protists was calculated following 2 alternative methods: 1 was based on the application of an allometric model of respiration to the measured size-abundance spectra, while the other was based on the measured rates of grazing (see 'Materials and methods'). For the latter method, we took the carbon ingestion rate of bacterivores to be $17 \mathrm{mg} \mathrm{C} \mathrm{m}^{-2}$ $\mathrm{d}^{-1}$, given that grazing by bacterivores is approximately equal to bacterial production in the open Atlantic Ocean (Zubkov et al. 2000). The allometric method yielded a mean value of respiration of $406 \mathrm{mg} \mathrm{C} \mathrm{m}^{-2} \mathrm{~d}^{-1}$, while the ingestion-based method resulted in an estimate of $171 \mathrm{mg} \mathrm{C} \mathrm{m}^{-2} \mathrm{~d}^{-1}$. We therefore estimated a range of respiration by heterotrophic protists in the NASE province of 171 to $406 \mathrm{mgC} \mathrm{m}^{-2}$ $\mathrm{d}^{-1}$ (Fig. 5). The sum of respiration by all microbial plankton groups would thus be in the range of 402 to $848 \mathrm{mg} \mathrm{C} \mathrm{m}^{-2} \mathrm{~d}^{-1}$. By contrast, community respiration, determined from $\mathrm{O}_{2}$ consumption during $24 \mathrm{~h}$ incubations in the dark and assuming a respiratory quotient of 0.89 (Robinson \& Williams 2005), was $1324 \pm$
$142 \mathrm{mgC} \mathrm{m}^{-2} \mathrm{~d}^{-1}$ (the range of mean values from all cruises was 577 to $1933 \mathrm{mg} \mathrm{C} \mathrm{m}^{-2} \mathrm{~d}^{-1}$ ). Mesozooplankton respiration is not included in the budget because this process is not represented in small-volume in vitro incubations. In any case, previous observations indicate that mesozooplankton respiration is less than an order of magnitude lower than microbial respiration in the central Atlantic Ocean (Isla et al. 2004).

\section{DISCUSSION}

\section{Seasonal variability and data representativeness}

To evaluate the representativenes of our data set, we compared the seasonal variability of phytoplankton chl $a$ and particulate primary production in the NASE province, as determined with bio-optical models based on satellite imagery (Longhurst 1998), and our own in situ observations (Fig. 3). For both variables, our observations show good agreement with the modelled data, both in terms of absolute values and seasonal trends. Although somewhat lower, the mean primary production rate in our study ( $271 \mathrm{mg} \mathrm{C} \mathrm{m}^{-2} \mathrm{~d}^{-1}$ ) compares reasonably well with the bio-optical estimate $(330 \mathrm{mgC}$ $\mathrm{m}^{-2} \mathrm{~d}^{-1}$ ). The difference may in part reflect the fact that the NASE province, as defined by Longhurst (1998), extends to $43^{\circ} \mathrm{N}$ and thus includes temperate waters that show enhanced productivity as compared to the 20 to $35^{\circ} \mathrm{N}$ latitudinal range considered here (Marañón et al. 2000). The vertical distribution and photic layer-integrated values of chl a concentration in our study agreed closely with the results reported by Li \& Harrison (2001) for the NASE province, based on an analysis of 18 stations visited in spring and autumn. Similarly, our measurements of mesozooplankton biomass generally fell within the seasonal trend that Finenko et al. (2003), using an extensive data set collected over a $40 \mathrm{yr}$ period, reported for the tropical North Atlantic Ocean (Fig. 4).

For other variables such as bacterial biomass and production, or biomass and grazing of heterotrophic protists, no climatology of seasonal changes is available at the biogeographic province scale. Li \& Harrison (2001) measured a mean bacterial biomass of $501 \mathrm{mg} \mathrm{C}$ $\mathrm{m}^{-2}$ in NASE, roughly similar to our estimate of $424 \mathrm{mgC} \mathrm{m}{ }^{-2}$. Recently, Alonso-Sáez et al. (2007) found an average bacterial production of $28 \mathrm{mg} \mathrm{C} \mathrm{m}^{-2}$ $\mathrm{d}^{-1}$ at 6 oligotrophic stations located in the NASE province. This value, although somewhat higher, compares well to our mean value of $17 \mathrm{mgC} \mathrm{m}^{-2} \mathrm{~d}^{-1}$ (Table 3). Although the choice of specific conversion factors may underlie some of the variability in bacterial biomass and production, we can also compare our measurements to those obtained at the Bermuda 
Atlantic Time Series (BATS) station in the Sargasso Sea, another open-ocean region with low microbial biomass and productivity (Steinberg et al. 2000, Mouriño-Carballido \& McGillicuddy 2006). During the period from 1988 to 2002, mean bacterial biomass and production rate in the upper $140 \mathrm{~m}$ at BATS were $630 \mathrm{mg} \mathrm{C} \mathrm{m}^{-2}$ and $33 \mathrm{mg} \mathrm{C} \mathrm{m}^{-2} \mathrm{~d}^{-1}$, respectively (calculated from data available at: http://bats.bbsr.edu, using the conversion factors given by Steinberg et al. 2000). Our mean values for bacterial biomass and production are lower by a factor of 1.5 and 2, respectively (Table 3). In addition, mean particulate primary production at BATS (459 $\mathrm{mg} \mathrm{C} \mathrm{m}^{-2} \mathrm{~d}^{-1}$ for 1988 to 2002) is also higher than our estimate for NASE by a factor of 1.7. These comparisons suggest that the western Sargasso Sea and, more specifically, the BATS site, is characterised by higher microbial biomass and activity than the eastern sector of the North Atlantic Subtropical Gyre between 22 and $34^{\circ} \mathrm{N}$. This difference may be related to the fact that, when the different nutrient injection mechanisms are taken into account, annual fertilisation of the euphotic layer is larger in the BATS site than in the NASE province (Cianca et al. in press).

\section{Autotrophic versus heterotrophic biomass}

Although no a priori connection can be established between the relative biomass contribution of autotrophs and heterotrophs and the metabolic balance of the community, our data do not support the existence of an 'inverted pyramid' of biomass in the microbial plankton of NASE, given that total phytoplankton biomass exceeded that of bacteria and heterotrophic protists by a factor of 1.7 (Fig. 5). The early reports of an overwhelming dominance of heterotrophic bacteria in the oligotrophic ocean, such that these organisms would represent 2 to 3 times more biomass than phytoplankton (Fuhrman et al. 1989, Cho \& Azam 1990), have been followed by other studies supporting a moderate dominance by bacteria (Caron et al. 1995, Buck et al. 1996), a codominance between the 2 groups (Li et al. 1992) or even a slight dominance by phytoplankton (Li \& Harrison 2001, Morán et al. 2004). Although these discrepancies reflect, in part, real spatio-temporal variability in the biomass of the different plankton groups, some methodological factors are likely to be involved. These include the overestimation of bacterial numbers when counting with epifluorescence microscopy (Zubkov et al. 1998), the use of too high carbon conversion factors for open ocean bacteria $\left(20 \mathrm{fgC} \mathrm{cell}^{-1}\right.$ instead of 6 to $12 \mathrm{fgC} \mathrm{Cell}^{-1}$; Fukuda et al. 1998, Gundersen et al. 2002) and the use of a too low mean C:chl a ratio for phytoplankton (20 to 40 instead of 60 to 80 ; Caron et al. 1995, Buck et al. 1996). There is growing evidence that phytoplankton inhabiting the upper layers of the subtropical oceans have $\mathrm{C}: \mathrm{chl}$ a ratios around 120 to 140 (see review by Marañón 2005). Assuming the C:chl a ratio below the DCM is around 30 (Veldhuis \& Kraay 2004, Pérez et al. 2006), the resulting value averaged over the entire photic layer should be at least 60 to 70. Using a C:chl a ratio of 40 to estimate total phytoplankton carbon, Li \& Harrison (2001) calculated a phytoplankton to bacterial $\mathrm{C}$ ratio of 2 in the NASE province. Had they used a C:chl a ratio of 60, their data would have resulted in a phytoplankton to bacterial C ratio of around 3, e.g. equal to our own estimate (Fig. 5). Therefore, both surveys (which together include 34 stations where both phytoplankton and bacterial biomass were estimated), strongly suggest that, on a euphotic layer-integrated basis, autotrophic biomass dominates over heterotrophic biomass in the microbial plankton community of the NASE province.

\section{Metabolic balance of the microbial plankton community}

Our analysis indicates that respiration consistently exceeds photosynthesis within the microbial plankton community of the eastern subtropical North Atlantic. Assuming a photosynthetic quotient (PQ) of 1, the input of allochthonous organic carbon needed to compensate for this net heterotrophic metabolism would be around $780 \mathrm{mgC} \mathrm{m}^{-2} \mathrm{~d}^{-1}$. In fact, the total input required to keep the integrity of the ecosystem must be even higher, because carbon losses due to sedimentation and mesozooplankton respiration are not taken into account in small-volume in vitro experiments. While mesozooplankton respiration is less than an order of magnitude lower than microbial respiration (Isla et al. 2004), sedimentation of organic carbon at the base of the euphotic layer in the NASE province ranges between 50 and $200 \mathrm{mg} \mathrm{C} \mathrm{m}^{-2} \mathrm{~d}^{-1}$ (Huskin et al. 2004). If one also considers the respiration of larger metazoans, the input of allochthonous organic carbon required to sustain the pelagic ecosystem in the NASE province is likely to be higher than $1 \mathrm{~g} \mathrm{C} \mathrm{m}^{-2} \mathrm{~d}^{-1}$.

The net heterotrophy of the microbial community in the NASE province has been reported before in studies that, in part, used data included in the present overview (Duarte et al. 2001, González et al. 2001, Serret et al. 2001, Robinson et al. 2002, Morán et al. 2004). It also agrees with the conclusions of previous work based on independent studies in the same region (Agustí et al. 2001, Harrison et al. 2001), which, importantly, reported community respiration rates similar to the ones we measured (in the range of 1000 to $2000 \mathrm{mg} \mathrm{C} \mathrm{m}^{-2} \mathrm{~d}^{-1}$ ). Unlike previous studies, however, our analysis combined measurements of the standing 
stocks and activity rates of all major microbial foodweb components, including bacteria, phytoplankton and heterotrophic protists. This allowed us to assess the extent to which community respiration rates are coherent with the summed respiration rates of each group of microbes. As shown in Fig. 5, the mean community respiration derived from $\mathrm{O}_{2}$ consumption rates during bottle incubations in the dark $(1324 \pm 142 \mathrm{mgC}$ $\mathrm{m}^{-2} \mathrm{~d}^{-1}$ ) clearly exceeds the range of estimated respiration by the various microbial groups (402 to $848 \mathrm{mgC}$ $\mathrm{m}^{-2} \mathrm{~d}^{-1}$ ). To evaluate the possible causes for this discrepancy, we shall now review each of the main fluxes involved.

We computed phytoplankton respiration by assuming that between 20 and $40 \%$ of carbon fixation during the photoperiod is respired during the night. The value of $20 \%$ is supported by the observations of Marra \& Barber (2004), conducted mainly in the temperate North Atlantic Ocean. It can be argued that phytoplankton inhabiting the warm and well illuminated upper waters of the subtropical gyres are likely to experience higher respiration rates (Geider 1992). In fact, Grande et al. (1998), during a cruise to the North Pacific Central Gyre, found that ${ }^{14} \mathrm{C}$ losses in the dark amounted to $26-36 \%$ of the ${ }^{14} \mathrm{C}$ fixed during the light period. In his review of phytoplankton respiration, Langdon (1993) concluded that the mean respiration to gross photosynthesis ratio in various taxonomic groups was in the range of 10 to $35 \%$. Thus, a value of $40 \%$ can be considered as an upper limit to constrain phytoplankton respiratory losses. Therefore, the value of $270 \mathrm{mg} \mathrm{C} \mathrm{m}^{-2} \mathrm{~d}^{-1}$ in Fig. 5 can be regarded as an upper estimate for phytoplankton respiration in the NASE province. Similarly, we can consider the value of $406 \mathrm{mg} \mathrm{C} \mathrm{m}^{-2} \mathrm{~d}^{-1}$ as an upper limit to the respiration by heterotrophic protists, given that it was calculated with an allometric model that is based on respiration rates measured in laboratory cultures. These are typically supplied with high amounts of resources and therefore sustain faster metabolic rates than those realised under natural conditions. Summing the upper estimates for phytoplankton respiration $\left(275 \mathrm{mg} \mathrm{C} \mathrm{m}^{-2} \mathrm{~d}^{-1}\right)$ and heterotrophic protist respiration $\left(406 \mathrm{mg} \mathrm{C} \mathrm{m}^{-2} \mathrm{~d}^{-1}\right)$ results in $681 \mathrm{mg} \mathrm{C} \mathrm{m}^{-2} \mathrm{~d}^{-1}$. This means that for total microbial respiration to match the rate of community respiration measured in vitro with the $\mathrm{O}_{2}$ method $\left(1324 \mathrm{mg} \mathrm{C} \mathrm{m}^{-2}\right.$ $\mathrm{d}^{-1}$ ), bacterial respiration should be around $640 \mathrm{mgC}$ $\mathrm{m}^{-2} \mathrm{~d}^{-1}$ (ca. $50 \%$ of community respiration).

Perhaps the most unexpected feature of the microbial carbon budget in Fig. 5 is the large difference between community respiration (1324 $\mathrm{mgC} \mathrm{m}^{-2} \mathrm{~d}^{-1}$ ) and bacterial respiration (96 to $172 \mathrm{mg} \mathrm{C} \mathrm{m}^{-2} \mathrm{~d}^{-1}$ ). This difference was not an artefact resulting from averaging each variable over different seasons and/or regions. If only concurrent measurements of bacterial production and community respiration are considered, the ratio between bacterial respiration (estimated by using a BGE of 0.09) and community respiration, integrated over the euphotic layer, was $0.17 \pm 0.045$ (range 0.06 to $0.32, \mathrm{n}=5$ ). This mismatch between community and bacterial respiration was found recently by Morán et al. (in press) for a meridional transect in the NASE and NATR provinces. Our analysis confirms this observation on the basis of a larger data set that also includes a component of seasonal variability. Although we did not conduct direct measurements of bacterial respiration in the NASE province, there is experimental and modelling evidence to indicate that bacteria dominate microbial respiration in unproductive ecosystems, accounting for more than $60 \%$ of total community respiration (Anderson \& Ducklow 2001, Biddanda et al. 2001, Robinson \& Williams 2005). Moreover, to explain the net heterotrophy of the unproductive open ocean, the input of allochthonous organic carbon has frequently been invoked (Duarte \& Agustí 1998, Duarte et al. 2001, Robinson et al. 2002), which implicitly assumes that bacterial metabolism should be responsible for processing most of the imported carbon. This provides an additional reason to expect that bacterial respiration should represent a major contribution to community respiration in areas of the ocean that are subsidised by external inputs of organic matter. In our budget, however, bacterial respiration represented only a modest fraction $(<15 \%)$ of total community respiration (Fig. 5).

The preceding calculations depend critically on the choice of the value for BGE. The values of BGE that we used to constrain our estimates of bacterial respiration were 0.09, experimentally determined by Alonso-Sáez et al. (2007) in the NASE province, and 0.15, the mean open-ocean value found by del Giorgio \& Cole (2000). A more recent review of BGE values in the open ocean reported a mean value of 0.12 (Alonso-Sáez et al. 2007, see their Web Appendix 3). Thus the available evidence suggests that $\mathrm{BGE}$, on a euphotic layer-integrated basis, is unlikely to get much lower than 0.10 . However, in order for bacteria to account for a moderate $50 \%$ of community respiration during our study (e.g. $640 \mathrm{mg} \mathrm{C} \mathrm{m}^{-2} \mathrm{~d}^{-1}$ ), and given the measured rates of bacterial production (17 $\left.\mathrm{mg} \mathrm{C} \mathrm{m}^{-2} \mathrm{~d}^{-1}\right)$, their average growth efficiency should be on the order of 0.025 . Such an extremely low efficiency is at the low end of the range of observed values in the oceans (del Giorgio \& Cole 2000), and it does not seem plausible that the ensemble of the bacterial community throughout the euphotic layer would continuously respire more than $97 \%$ of the assimilated carbon.

An alternative possibility is that we have grossly underestimated bacterial production. However, our measurements are only a factor of 2 lower than the 
average production rates measured at BATS during 1991 to 1998 (Steinberg et al. 2001) and fall within the range of values reported by Agustí et al. (2001), Harrison et al. (2001) and Alonso-Sáez et al. (2007) for the NASE province. Furthermore, the mean ratio of bacterial production to ${ }^{14} \mathrm{C}$-based particulate primary production in our data set (0.063) coincided with that observed at BATS (0.072). In any case, even if we doubled our bacterial production rates and applied a low BGE of 0.09, bacterial respiration would be around $340 \mathrm{mg} \mathrm{C} \mathrm{m}^{-2} \mathrm{~d}^{-1}$, which is only $25 \%$ of the $\mathrm{O}_{2}$-derived community respiration. The sum of our upper estimates for the respiration of each microbial group is around $850 \mathrm{mg} \mathrm{C} \mathrm{m}^{-2} \mathrm{~d}^{-1}$, which is well below the measured community respiration of $1324 \pm 142 \mathrm{mgC} \mathrm{m}^{-2}$ $\mathrm{d}^{-1}$. We thus conclude that it is not possible to reconcile the measured rates of community respiration with the respiratory fluxes sustained by the various groups of microbes.

\section{General implications}

It may well be that the inconsistency between bacterial and community respiration identified here for the NASE province is a widespread occurrence in the open ocean (Table 6). In their review of respiration in surface marine waters, Robinson \& Williams (2005) concluded that the mean integrated open-ocean respiration rate is $116 \mathrm{mmolO}_{2} \mathrm{~m}^{-2} \mathrm{~d}^{-1}$, which would be approximately equivalent to $1200 \mathrm{mgC} \mathrm{m}^{-2} \mathrm{~d}^{-1}$. This figure is at least 3 times larger than the average ${ }^{14} \mathrm{C}$ based photosynthesis in the open ocean (ca. $350 \mathrm{mgC}$ $\mathrm{m}^{-2} \mathrm{~d}^{-1}$; Longhurst et al. 1995). As has been frequently pointed out, this difference can be explained by assuming that gross photosynthesis exceeds the rate of ${ }^{14} \mathrm{C}$ fixation into particulate matter by a factor of 1.5 to 2 (del Giorgio \& Duarte 2002, Robinson \& Williams 2005). Inputs of organic matter from adjacent productive areas and from the atmosphere may help further in closing the balance. However, the need remains to reconcile bacterial metabolism with community respira- tion, because an established view in aquatic microbial ecology is that bacteria dominate carbon cycling in oligotrophic waters (Sherr \& Sherr 1996, del Giorgio et al. 1997, Biddanda et al. 2001, Robinson \& Williams 2005). Bacterial production in the ocean is typically $10 \%$ of ${ }^{14} \mathrm{C}$-based primary production (Ducklow 2000), which translates into a mean value of around $35 \mathrm{mgC}$ $\mathrm{m}^{-2} \mathrm{~d}^{-1}$. Taking into account the mean BGE $(0.15 \%)$ reported for the open ocean (del Giorgio \& Cole 2000), the average bacterial respiration would then be approximately $200 \mathrm{mg} \mathrm{C} \mathrm{m}^{-2} \mathrm{~d}^{-1}$. This figure is $<20 \%$ of total community respiration and is therefore at odds with the expected dominance of bacterial respiration (Table 6).

These calculations suggest that it may be difficult to reconcile current estimates of DCR with the existing knowledge of bacterial production and growth efficiency in the open ocean. As pointed out by Briand et al. (2004), a potential methodological problem lies in combining measurements of metabolic rates conducted over widely differing time scales $(0.5$ to $4 \mathrm{~h}$ for bacterial production versus $24 \mathrm{~h}$ for community respiration). Long incubations may overestimate the ratio between respiration and photosynthesis as a result of a reduction in the abundance and activity of picophytoplankton (Fernández et al. 2003) and, more importantly, an increase in the abundance, cell size and cell-specific activity of heterotrophic bacteria (Pomeroy et al. 1994, Sherr et al. 1999). Increases in bacterial numbers by a factor of 2 to 4 have been reported to occur after $24 \mathrm{~h}$ in vitro incubations (Pomeroy et al. 1994, Gattuso et al. 2002). However, when hydrodynamic conditions are stable, in situ bacterial abundance shows only modest changes $(<20$ to $30 \%$ ) over timescales of $24 \mathrm{~h}$ (Kuipers et al. 2000, Tsai et al. 2005). These increases in bacterial abundance and activity have been related to the reduction in encounter rates between bacteria and their grazers in incubation bottles (Pomeroy et al. 1994) and also to the release of labile substrates as a result of sample manipulation and confinement (see Sherr et al. 1999 and references therein). Thus, a recommendable

Table 6. Approximate mean values for different metabolic properties of microbial plankton communities in the open ocean. Rates are integrated over the euphotic layer

\begin{tabular}{|lcl|}
\hline Property & Mean value & \multicolumn{1}{c}{ Source } \\
\hline${ }^{14} \mathrm{C}$-based particulate primary production $\left(\mathrm{mg} \mathrm{C} \mathrm{m}^{-2} \mathrm{~d}^{-1}\right)$ & 350 & Longhurst et al. (1995) \\
Community respiration $(\mathrm{CR})\left(\mathrm{mg} \mathrm{C} \mathrm{m}^{-2} \mathrm{~d}^{-1}\right)$ & 1100 & Robinson \& Williams (2005) \\
Bacterial production $/{ }^{14} \mathrm{C}$-based particulate primary production & 0.10 & Ducklow (2000) \\
Bacterial production $\left(\mathrm{mg} \mathrm{C} \mathrm{m}{ }^{-2} \mathrm{~d}^{-1}\right)$ & 35 & Longhurst et al. (1995), Ducklow (2000) \\
Bacterial growth efficiency & 0.15 & del Giorgio \& Cole (2000) \\
Bacterial respiration (BR) $\left(\mathrm{mg} \mathrm{C} \mathrm{m}^{-2} \mathrm{~d}^{-1}\right)$ & 200 & Ducklow (2000), del Giorgio \& Cole (2000) \\
BR/CR & $<0.2$ & \\
\hline
\end{tabular}


practice would be to monitor cell abundance during $24 \mathrm{~h}$ incubations using parallel bottles and to compare in vitro changes to those occurring in situ (e.g. Sherr et al. 1999). Some attention should be given to the possibility that $24 \mathrm{~h}$ in vitro incubations overestimate the community respiration to photosynthesis ratio, given that high rates of $\mathrm{O}_{2}$ consumption are difficult to reconcile with persistent $\mathrm{O}_{2}$-supersaturation over most of the euphotic layer (Fig. 2D). In fact, comparing our estimates of total respiration by all microbial groups (402 to $848 \mathrm{mgC} \mathrm{m}^{-2} \mathrm{~d}^{-1}$ ) and gross photosynthesis by phytoplankton (481 to $616 \mathrm{mgC} \mathrm{m}^{-2}$ $\mathrm{d}^{-1}$, one would conclude that the microbial community in the NASE province is close to metabolic balance (Fig. 5).

On the other hand, several methodological problems involved in the measurement of bacterial production rates may confound their interpretation in terms of actual carbon fluxes. For instance, typical measurements of bacterial production yield net rates of production (Ducklow 2000), which, if grazing losses during the experiments are high, may lead to underestimating the real bacterial metabolic rates. Another source of uncertainty in conventional determinations of bacterial production is that short-term experiments are usually conducted at a particular time of day, therefore missing the diel variability that occurs in bacterial metabolic activity. Bacterial activity may peak at noon or during the early afternoon (Gasol et al. 1998, Winter et al. 2004), whereas most measurements of bacterial production are typically conducted at dawn or early in the morning, which could lead to potential underestimation of bacterial production rates. In the present study, however, bacterial production measurements were conducted at noon during 2 cruises and in the early morning during the other 2 . It is therefore unlikely that sampling time had a major impact on our estimates of bacterial production. Finally, leucine uptake experiments are usually carried out in the dark, which, depending on community composition and environmental conditions, can lead to an overestimation (Morán et al. 2001) or underestimation (Church et al. 2004) of bacterial production as measured under in situ light conditions. In any event, our estimates of both community respiration and bacterial production agree with those reported previously by numerous studies, and therefore the discrepancy between these 2 types of measurements is not restricted to the NASE province but is likely to apply to the oligotrophic open ocean in general.

In conclusion, it must be acknowledged that difficulties exist in combining results from different experimental methods and extrapolating from in vitro observations to biogeochemical fluxes over large expanses of the ocean. Our analysis highlights important gaps in our understanding of the relationship between community respiration and the metabolic activity of the different microbial groups. Without resolving the inconsistencies in the carbon budget of the microbial plankton community, it is unlikely that we will be able to determine unequivocally the metabolic balance of the oligotrophic open ocean, let alone constrain the net contribution of the marine biota to the global carbon cycle.

Acknowledgements. We thank all who contributed to sample collection and analysis, as well as the captains and crews of all research vessels involved. Comments by 3 anonymous reviewers are also acknowledged. B.M. and E.T. were supported by a 'Juan de la Cierva' fellowship from the Spanish Ministry of Education and Science (MEC). V.P. was supported by a post-graduate research fellowship from MEC. This work was made possible by grants from the European Union (CANIGO project), the Spanish Ministry of Science and Education (projects CIRCANA and CARPOS) and the UK National Environmental Research Council (Atlantic Meridional Transect consortium). This is AMT contribution number 149.

\section{LITERATURE CITED}

Agustí S, Duarte CM, Vaqué D, Hein M, Gasol JM, Vidal M (2001) Food-web structure and elemental (C, N and P) fluxes in the eastern tropical North Atlantic. Deep-Sea Res Part II 48:2295-2321

Alonso-Sáez L, Gasol JM, Arístegui J, Vilas JC, Vaqué D, Duarte CM, Agustí S (2007) Large-scale variability in surface bacterial carbon demand and growth efficiency in the subtropical North East Atlantic Ocean. Limnol Oceanogr 52:533-546

Anderson TR, Ducklow HW (2001) Microbial loop carbon cycling in ocean environments studied using a simple steady-state model. Aquat Microb Ecol 26:37-49

Biddanda B, Ogdahl M, Cotner J (2001) Dominance of bacterial metabolism in oligotrophic relative to eutrophic waters. Limnol Oceanogr 46:730-739

Bode A, Barquero S, Varela M, Braun JG, de Armas D (2001) Pelagic bacteria and phytoplankton in oceanic waters near the Canary Islands in summer. Mar Ecol Prog Ser 209:1-17

Briand E, Pringault O, Jacquet S, Torréton JP (2004) The use of oxygen microprobes to measure bacterial respiration for determining bacterioplankton growth efficiency. Limnol Oceanogr Methods 2:406-416

Buck KR, Chavez FP, Campbell L (1996) Basin-wide distribution of living carbon components and the inverted trophic pyramid of the central gyre of the North Atlantic Ocean, summer 1993. Aquat Microb Ecol 10:283-298

Caron DA, Dam HG, Kremer P, Lessard EJ and 6 others (1995) The contribution of microorganisms to particulate carbon and nitrogen in surface waters of the Sargasso Sea near Bermuda. Deep-Sea Res Part I 42:943-972

Cho BC, Azam F (1990) Biogeochemical significance of bacterial biomass in the ocean's euphotic zone. Mar Ecol Prog Ser 63:253-259

Church MJ, Ducklow HW, Karl DA (2004) Light dependence of $\left[{ }^{3} \mathrm{H}\right]$-leucine incorporation in the oligotrophic North Pacific ocean. Appl Environ Microbiol 70:4079-4087 
Cianca A, Helmke P, Mouriño B, Rueda MJ, Llinás O, Neuer S (2007) Decadal analysis of hydrography and in situ nutrient budgets in the western and eastern North Atlantic subtropical gyre. J Geophys Res 112:C07025, doi: 10.1029/2006JC003788

del Giorgio PA, Cole JJ (2000) Bacterial energetics and growth efficiency. In: Kirchman DL (ed) Microbial ecology of the oceans. Wiley-Liss, New York, p 289-325

del Giorgio PA, Duarte CM (2002) Respiration in the open ocean. Nature 420:379-384

del Giorgio PA, Cole JJ, Cimbleris A (1997) Respiration rates in bacteria exceed phytoplankton production in unproductive aquatic systems. Nature 385:148-151

Duarte CM, Agustí S (1998) The $\mathrm{CO}_{2}$ balance of unproductive aquatic ecosystems. Science 281:234-236

Duarte CM, Agustí S, Arístegui J, González N, Anadón R (2001) Evidence for a heterotrophic subtropical northeast Atlantic. Limnol Oceanogr 46:425-428

Duarte CM, Dachs J, Llabrés M, Alonso-Laita P, Gasol JM, Tovar-Sánchez A, Sañudo-Wilhemy S, Agustí S (2006) Aerosol inputs enhance new production in the subtropical northeast Atlantic. J Geophys Res 111:G04006, doi: 10.1029/2005JG000140

Ducklow H (2000) Bacterial production and biomass in the ocean. In: Kirchman DL (ed) Microbial ecology of the oceans. Wiley-Liss, New York, p 85-120

Fenchel T, Finlay BJ (1983) Respiration rates in heterotrophic, free-living protozoa. Microb Ecol 9:99-122

Fernández E, Marañón E, Morán XAG, Serret P (2003) Potential causes for the unequal contribution of picophytoplankton to total biomass and productivity in oligotrophic waters. Mar Ecol Prog Ser 254:101-109

Finenko ZZ, Piontkovski SA, Williams R, Mishonov AV (2003) Variability of phytoplankton and mesozooplankton biomass in the subtropical and tropical Atlantic Ocean. Mar Ecol Prog Ser 250:125-144

Fuhrman JA, Sleeter TD, Carlson CA, Proctor LM (1989) Dominance of bacterial biomass in the Sargasso Sea and its ecological implications. Mar Ecol Prog Ser 57:207-217

Fukuda R, Ogawa H, Nagata T, Koike I (1998) Direct determination of carbon and nitrogen contents of natural bacterial assemblages in marine environments. Appl Environ Microbiol 64:3352-3358

Gasol JM, Doval MD, Pinhassi J, Calderon-Paz JI, GuixaBoixareu N, Vaqué D, Pedrós-Alió C (1998) Diel variations in bacterial heterotrophic activity and growth in the northwestern Mediterranean Sea. Mar Ecol Prog Ser 164: 107-124

Gattuso JP, Peduzzi S, Pizay MD, Tonolla M (2002) Changes in freshwater bacterial community composition during measurements of microbial and community respiration. J Plankton Res 24:1197-1206

Geider RJ (1992) Respiration: taxation without representation? In: Falkowski PG, Woodhead AD (eds) Primary productivity and biogeochemical cycles in the sea. Plenum Press, New York, p 333-360

González N, Anadón R, Mouriño B, Fernández E, Sinha B, Escánez J, de Armas D (2001) The metabolic balance of the planktonic community in the $\mathrm{N}$ Atlantic subtropical gyre. Limnol Oceanogr 46:946-952

Grande KD, Williams PJL, Marra J, Purdie DA, Heinemann K, Eppely RW, Bender ML (1998) Primary production in the North Pacific gyre: a comparison of rates determined by ${ }^{14} \mathrm{C}, \mathrm{O}_{2}$ concentration and ${ }^{18} \mathrm{O}$ methods. Deep-Sea Res 36 : 1621-1634

Gundersen K, Heldal M, Norland S, Purdie DA, Knap AH (2002) Elemental C, N, and P cell content of individual bacteria collected at the Bermuda Atlantic Time-Series Study (BATS) site. Limnol Oceanogr 47:1525-1530

Harrison WG, Arístegui J, Head EJH, Li WKW, Longhurst AR, Sameoto DD (2001) Basin-scale variability in plankton biomass and community metabolism in the sub-tropical North Atlantic Ocean. Deep-Sea Res Part II 48:2241-2269

Huskin I, Anadón R, Medina G, Head RN, Harris RP (2001) Mesozooplankton distribution and copepod grazing in the subtropical Atlantic near the Azores: influence of mesoscale structures. J Plankton Res 23:671-691

Huskin I, Viesca L, Anadon R (2004) Particle flux in the Subtropical Atlantic near the Azores: influence of mesozooplankton. J Plankton Res 26:403-415

Isla JA, Llope M, Anadón R (2004) Size-fractionated mesozooplankton biomass, metabolism and grazing along a $50^{\circ} \mathrm{N}$ to $30^{\circ} \mathrm{S}$ transect of the Atlantic Ocean. J Plankton Res 26: 1301-1313

Karl DM (1999) A sea of change: biogeochemical variability in the North Pacific subtropical gyre. Ecosystems 2:181-214

Karl DM, Laws EA, Morris P, Williams PJL, Emerson S (2003) Metabolic balance of the open sea. Nature 426:32

Kuipers B, van Noort GJ, Vosjan J, Herndl GJ (2000) Diel periodicity of bacterioplankton in the euphotic zone of the subtropical Atlantic Ocean. Mar Ecol Prog Ser 201:13-25

Langdon C (1993) The significance of respiration in production measurements based on oxygen. ICES Mar Sci Symp 197:69-78

Li WKW, Harrison WG (2001) Chlorophyll, bacteria and picophytoplankton in ecological provinces of the North Atlantic. Deep-Sea Res Part II 48:2271-2293

Li WKW, Dickie PM, Irwin BD, Wood AM (1992) Biomass of bacteria, cyanobacteria, prochlorophytes and photosynthetic eukaryotes in the Sargasso Sea. Deep-Sea Res Part I 39:501-519

Longhurst A (1998) Ecological geography of the sea. Academic Press, San Diego, CA

Longhurst A, Sathyendranath S, Platt T, Caverhill C (1995) An estimate of global primary production in the ocean from satellite radiometer data. J Plankton Res 17:1245-1271

Marañón E (2005) Phytoplankton growth rates in the Atlantic subtropical gyres. Limnol Oceanogr 50:299-310

Marañón E, Holligan PM, Varela M, Mouriño B, Bale AJ (2000) Basin-scale variability of phytoplankton biomass, production and growth in the Atlantic Ocean. Deep-Sea Res Part I 47:825-857

Marañón E, Holligan PM, Barciela R, González N, Mouriño B, Pazó MJ, Varela M (2001) Patterns of phytoplankton sizestructure and productivity in contrasting open ocean environments. Mar Ecol Prog Ser 216:43-56

Marra J, Barber RT (2004) Phytoplankton and heterotrophic respiration in the surface layer of the ocean. Geophys Res Lett 31:L09314, doi:10.1029/2004GL019664

Morán XAG, Massana R, Gasol JM (2001) Light conditions affect the measurement of oceanic bacterial production via leucine uptake. Appl Environ Microbiol 67:3795-3801

Morán XAG, Fernández E, Pérez V (2004) Size-fractionated primary production, bacterial production and net community production in subtropical and tropical domains of the oligotrophic NE Atlantic in autumn. Mar Ecol Prog Ser 274:17-29

Morán XAG, Fernández E, Pérez V (in press) Mismatch between community and bacterial respiration in the NE Atlantic open ocean: what causes high respiration in oligotrophic waters? J Mar Res

Mouriño B, Fernández E, Pingree R, Sinha B, Escánez J, de Armas D (2005) Constraining effect of mesoscale features on carbon budget of photic layer in the NE subtropical 
Atlantic. Mar Ecol Prog Ser 287:45-52

Mouriño-Carballido B, McGillicuddy DJ (2006) Mesoscale variability in the metabolic balance of the Sargasso Sea. Limnol Oceanogr 51:2675-2689

Pérez V, Fernández E, Marañón E, Morán XAG, Zubkov MV (2006) Vertical variability of phytoplankton biomass, production and growth in the Atlantic subtropical gyres. Deep-Sea Res Part I 53:1616-1634

Peters RH (1983) The ecological implications of body size. Cambridge University Press, Cambridge

Pomeroy LR, Sheldon JE, Sheldon WM (1994) Changes in bacterial numbers and leucine assimilation during estimations of microbial respiratory rates in seawater by the precision Winkler method. Appl Environ Microbiol 60: 328-332

Quevedo M, Anadón R (2001) Protist control of phytoplankton growth in the subtropical north-east Atlantic. Mar Ecol Prog Ser 221:29-38

Quevedo M, Viesca L, Anadón R, Fernández E (2003) The protistan microzooplankton community in the oligotrophic north-eastern Atlantic: large- and mesoscale patterns. J Plankton Res 25:551-563

Ridgwell AJ, Maslin MA, Watson AJ (2002) Reduced effectiveness of terrestrial carbon sequestration due to an antagonistic response of ocean productivity. Geophys Res Lett 29: doi:10.1029/2001GL014304

Robinson C, Williams PJleB (2005) Respiration and its measurement in surface marine waters. In: del Giorgio $\mathrm{P}_{\text {, }}$ Williams PJL (eds) Respiration in aquatic ecosystems. Oxford University Press, Oxford

Robinson C, Serret P, Tilstone G, Teira E, Zubkov MV, Rees AP, Woodward EMS (2002) Plankton respiration in the Eastern Atlantic Ocean. Deep-Sea Res Part I 49:787-813

Sarmiento JL, Hughes TMC, Stouffer RJ, Manabe S (1998) Simulated response of the ocean carbon cycle to anthropogenic climate warming. Nature 393:245-249

Serret P, Robinson C, Fernández E, Teira E, Tilstone G (2001) Latitudinal variation of the balance between plankton photosynthesis and respiration in the eastern Atlantic Ocean. Limnol Oceanogr 46:1642-1652

Sherr EB, Sherr BF (1996) Temporal offset in oceanic produc-

Editorial responsibility: Gerhard Herndl,

Den Burg, Texel, The Netherlands tion and respiration processes implied by seasonal changes in atmospheric oxygen: the role of heterotrophic microbes. Aquat Microb Ecol 11:91-100

Sherr EB, Sherr BF, Sigmon CT (1999) Activity of marine bacteria under incubated and in situ conditions. Aquat Microb Ecol 20:213-223

Steinberg DK, Carlsson CA, Bates NR, Johnson RJ, Michaels AF, Knap AH (2001) Overview of the US JGOFS Bermuda Atlantic Time-series Study (BATS): a decade-scale look at ocean biology and biogeochemistry. Deep-Sea Res Part II 48:1405-1447

Teira E, Pazó MJ, Quevedo M, Fuentes MV, Niell FX, Fernández E (2003) Rates of dissolved organic carbon production and bacterial activity in the eastern North Atlantic Subtropical Gyre during summer. Mar Ecol Prog Ser 249: 53-67

Teira E, Mouriño B, Marañón E, Pérez V and 6 others (2005) Variability of chlorophyll and primary production in the Eastern North Atlantic Subtropical Gyre: potential factors affecting phytoplankton activity. Deep-Sea Res Part I 52: 569-588

Tsai A, Chiang K, Chang J, Gong G (2005) Seasonal diel variations of picoplankton and nanoplankton in a subtropical western Pacific coastal ecosystem. Limnol Oceanogr 50: 1221-1231

Veldhuis MJW, Kraay GW (2004) Phytoplankton in the subtropical Atlantic Ocean: towards a better assessment of biomass and composition. Deep-Sea Res Part I 51:507-530

Winter C, Herndl GJ, Weinbauer MG (2004) Diel cycles in viral infection of bacterioplankton in the North Sea. Aquat Microb Ecol 35:207-216

Zubkov MV, Sleigh MA, Tarran GA, Burkill PH, Leakey RJG (1998) Picoplankton community structure on an Atlantic transect from $50^{\circ} \mathrm{N}$ to $50^{\circ} \mathrm{S}$. Deep-Sea Res Part I 45: $1339-1355$

Zubkov MV, Sleigh MA, Burkill PH, Leakey RJG (2000) Bacterial growth and grazing loss in contrasting areas of North and South Atlantic. J Plankton Res 22:685-711

Zubkov MV, Sleigh MA, Burkill PH (2001) Heterotrophic bacterial turnover along the $20^{\circ} \mathrm{W}$ meridian between $59^{\circ} \mathrm{N}$ and $37^{\circ} \mathrm{N}$ in July 1996. Deep-Sea Res Part II 48:987-1001

Submitted: October 16, 2006; Accepted: May 22, 2007

Proofs received from author(s): July 20, 2007 